Article

\title{
Transport and Retention of Nitrogen, Phosphorus and Carbon in North America's Largest River Swamp Basin, the Atchafalaya River Basin
}

\section{Y. Jun Xu}

School of Renewable Natural Resources, Louisiana State University Agricultural Center, Baton Rouge, LA 70803, USA; E-Mail: yjxu@1su.edu; Tel.: +1-225-578-4168; Fax: +1-225-578-4227

Received: 19 February 2013; in revised form: 18 March 2013 / Accepted: 22 March 2013 /

Published: 3 April 2013

\begin{abstract}
Floodplains and river corridor wetlands may be effectively managed for reducing nutrients and carbon. However, our understanding is limited to the reduction potential of these natural riverine systems. This study utilized the long-term (1978-2004) river discharge and water quality records from an upriver and a downriver location of the Atchafalaya River to quantify the inflow, outflow, and inflow-outflow mass balance of total Kjeldahl nitrogen $(\mathrm{TKN}=$ organic nitrogen + ammonia nitrogen), nitrate + nitrite nitrogen $\left(\mathrm{NO}_{3}+\mathrm{NO}_{2}\right)$, total phosphorous (TP), and total organic carbon (TOC) through the largest river swamp basin in North America. The study found that, over the past 27 years, the Atchafalaya River Basin (ARB) acted as a significant sink for TKN (annual retention: $24 \%)$, TP $(41 \%)$, and TOC $(12 \%)$, but a source for $\mathrm{NO}_{3}+\mathrm{NO}_{2}$ nitrogen $(6 \%)$. On an annual basis, ARB retained 48,500 $\mathrm{t}$ TKN, 16,900 $\mathrm{t} \mathrm{TP}$, and 167,100 $\mathrm{t}$ TOC from the river water. The retention rates were closely and positively related to the river discharge with highs during the winter and spring and lows in the late summer. The higher $\mathrm{NO}_{3}+\mathrm{NO}_{2}$ mass outflow occurred throughout spring and summer, indicating an active role of biological processes on nitrogen as water and air temperatures in the basin rise.
\end{abstract}

Keywords: nutrient removal; riverine nutrients; riverine carbon; eutrophication; riverine wetlands; Mississippi-Atchafalaya River system 


\section{Introduction}

The Atchafalaya River pours approximately $182 \mathrm{~km}^{3}$ of water into the Gulf of Mexico (GOM) each year, representing about $24 \%$ of the total freshwater inflow to the world's ninth largest ocean from the U.S. continent. This river is a major distributary that carries, during most years, $25 \%-35 \%$ of the Mississippi River's flow and the entire Red River into GOM. Despite contributing nearly one third of the Atchafalaya's flow, the Red River has been found to export only a marginal amount of nitrate nitrogen $(\sim 3 \%)$ to the Atchafalaya River [1]. Nutrients and carbon found in the Atchafalaya River mainly originate from the upper Mississippi River Basin. During the past half century, increased nutrient loads have been observed in the lower Mississippi River Basin waters [2-4]. The nutrient enrichment, especially nitrate nitrogen, has been attributed to exacerbating coastal water eutrophication, favoring harmful algal blooms, aggravating oxygen depletion and altering marine food webs in the northern Gulf of Mexico [3,5-8].

To reduce the excess nutrient input to GOM, an action plan was released in 2008 by the Mississippi River/Gulf of Mexico Watershed Nutrient Task Force [10]. The action plan called for completing and implementing comprehensive nitrogen and phosphorus reduction strategies for states within the Mississippi/Atchafalaya River Basin with one major goal - to reduce the five-year running average areal extent of the Gulf of Mexico hypoxic zone to less than 5000 square kilometers by the year 2015 . A number of options were considered including diversion of the nitrogen-rich Mississippi water into riverine floodplain wetland systems. Our understanding, however, is limited regarding the actual retention rates of nitrogen and phosphorus from the overflowing waters through these natural river corridor wetlands.

The Atchafalaya River is confined by levees on its east and west sides, encompassing a regulated floodplain basin with bayous, canals, lakes, backwater swamps, and bottomland forests. The water level within the swamp river basin can fluctuate as much as 6 meters on a normal yearly basis, creating a domain for hydrologic connectivity, flood pulses, and river chemistry in the Atchafalaya. During extreme high flows of the Mississippi River, such as the 1973 and the recent 2011 Mississippi River spring floods, more water is diverted into the Atchafalaya through a flood control structure - the Morganza Spillway, resulting in extensive inundation of the floodplain. Although more studies have been conducted during the past two decades, hydrology and hydrologic influences on carbon and nutrient transports in this large floodplain system are not well understood. The knowledge can be especially important as the U.S. is taking aggressive steps to reduce nutrient loads and control hypoxia in the northern Gulf of Mexico [9].

In recent studies, $\mathrm{Xu}$ [10] and $\mathrm{Xu}$ and Patil [11] estimated total nitrogen and carbon loads in the Atchafalaya for 1978-2002. This study is a continuation of the previous studies with three specific objectives: (1) to refine mass loading models for estimating carbon and nitrogen with additional 2-year (2003-2004) river discharge and water quality data; (2) to determine phosphorus mass inflow and outflow in the Atchafalaya River Basin; and (3) to analyze hydrologic influences on carbon, nitrogen and phosphorus retention for the basin in a holistic approach. The overall goal of this study is to determine if this large river basin functions as a sink or source for riverine nutrients and organic carbon. 


\section{Methods}

\subsection{Atchafalaya River Basin}

The Atchafalaya River flows southerly for about $200 \mathrm{~km}$ into GOM (Figure 1). The river begins at a geographical location of $91^{\circ} 42^{\prime} 48^{\prime \prime} \mathrm{W}$ and $31^{\circ} 03^{\prime} 46^{\prime \prime} \mathrm{N}$, where the Red River is joined by about $30 \%$ of the Mississippi River's flow that is diverted through the Old River Control Structure into the Old River outflow channel. The Atchafalaya River is confined by levees that surround it on the north, east and west for 20-35 km wide and $182 \mathrm{~km}$ long (channel distance), with a hydraulic gradient of only about $5 \mathrm{~m}$. Based on the delineation with LIDAR elevation data, the total area confined is approximately $3923 \mathrm{~km}^{2}$, in which wooded lowland and cypress-tupelo surface flow swamp are predominant. This engineered river system is part of a flood-control project designed to provide a diversion for extreme flooding on the Mississippi River.

Figure 1. Geographical location of the Atchafalaya River Basin. Discharge and water quality records were obtained at Simmesport (upstream location) and Wax Lake and Morgan City (downstream locations). The river distance from Simmesport to Morgan City is approximately $182 \mathrm{~km}$.

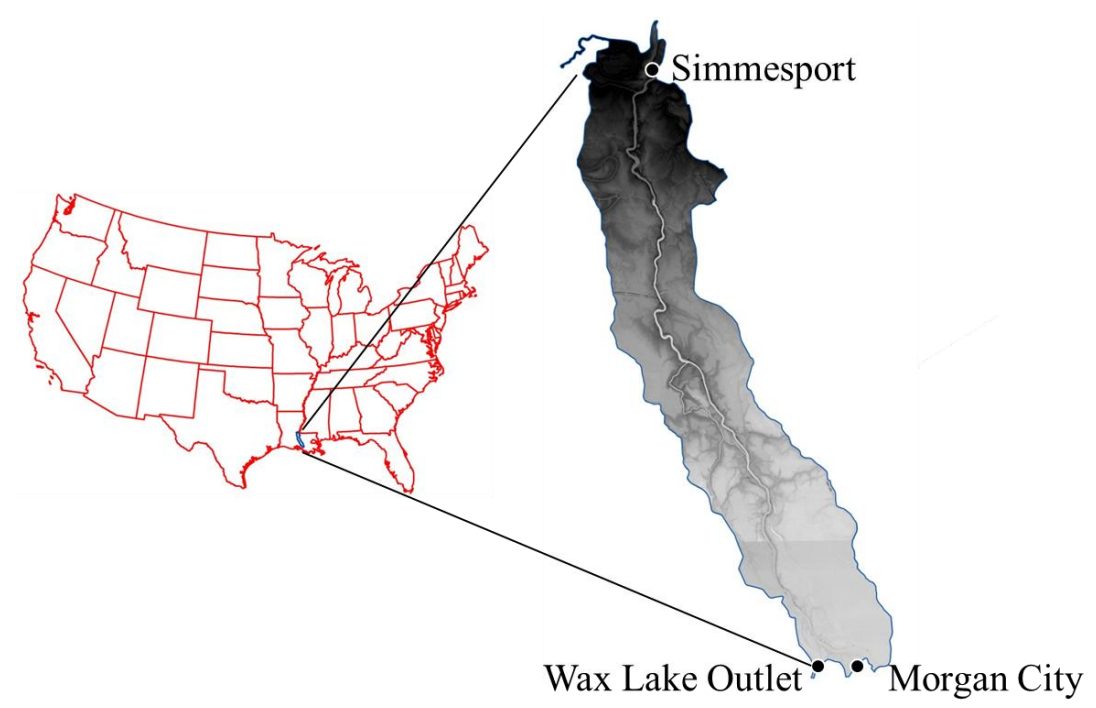

Climate in the Atchafalaya River Basin is humid, subtropical with typically mild winters, hot summers, and abundant rainfall (up to over $1500 \mathrm{~mm}_{\text {year }}{ }^{-1}$ ). Soils in the high and intermediate areas on the natural levees range from very fine sandy loams and silty loams, to silty clay loams [12]. Poorly drained loamy and clayey soils are present in the lower positions on natural levees and in back-swamps on the flood plain of the Atchafalaya River. Surface hydrology of the basin plays a vital role for the diversity, health and dynamics of the swamp ecosystems.

\subsection{River Discharge and Water Quality Data}

Daily river discharge data from 1978 to 2004 were obtained from the United States Army Corps of Engineers (USACE) and the United States Geological Survey (USGS) for Simmesport (USGS Station\#: 07381490; USACE Station\#: 03045), Morgan City (07381600; 03780) and Wax Lake 
Outlet (07381590; 03720). Water quality data were obtained from the Louisiana Department of Environmental Quality (LDEQ) for Simmesport (LDEQ Station\#: 0022) and Morgan City (0039). The water quality data included monthly measurements on a series of chemical and physical parameters, of which concentrations of total organic carbon (TOC), total Kjeldahl nitrogen (TKN, which is the sum of organic nitrogen and ammonia nitrogen), and nitrate plus nitrite nitrogen $\left(\mathrm{NO}_{3}+\mathrm{NO}_{2}\right)$, and total phosphorus (TP) were used in this study.

The water quality measurements covered the period from 1978 to 2004 at the Morgan City monitoring station, but, at the Simmesport monitoring station, data were only available for the years 1978-1990 and 2002-2004. No water quality data were available for Wax Lake Outlet. It is assumed that there was no significant difference in carbon and nutrient concentrations of the waters between these two outlets. Therefore, estimation of carbon, nitrogen and phosphorus for the outflow used the concentrations of the elements measured at Morgan City.

\subsection{Estimation of Mass Transport of Carbon, Nitrogen and Phosphorus}

A log-linear regression model was developed to estimate daily loads of total organic carbon, total nitrogen (TKN and $\mathrm{NO}_{3}+\mathrm{NO}_{2}$ ), and total phosphorus at the upstream and downstream locations. The regression can be described in a general equation as below:

$$
\ln \left(S_{i}(t)\right)=b_{0}+b_{1} \ln \left(Q_{\text {day }}(t)\right)+\varepsilon(t)
$$

where $Q_{d a y}$ represents daily discharge in liters, $S(t)$ daily loads in grams, $i$ the type of element, and $\varepsilon(t)$ is an error term assumed to be normally distributed. The regression was performed using SAS Statistical Software [13]. The fitted parameters and the statistical measures of fitness are summarized in Table 1.

Table 1. Parameter estimates ( $b 0$ and $b 1$ ), root of mean square error (RMSE), and sampling size (n) used for calculating [see Equation (1)] daily mass transport of total organic carbon (TOC), total Kjeldahl nitrogen (TKN), nitrate and nitrite nitrogen $\left(\mathrm{NO}_{3}+\mathrm{NO}_{2}\right)$, and total phosphorus (TP).

\begin{tabular}{ccccccc}
\hline \multirow{5}{*}{ Inflow } & & $\boldsymbol{b 0}$ & $\boldsymbol{b 1}$ & R-square & RMSE & $\boldsymbol{n}$ \\
\hline \multirow{5}{*}{ Outflow } & $\mathrm{TOC}$ & -10.037 & 1.183 & 0.82 & 0.341 & 145 \\
& $\mathrm{TKN}$ & -12.404 & 1.201 & 0.82 & 0.323 & 149 \\
& $\mathrm{NO}_{3}+\mathrm{NO}_{2}$ & -10.227 & 1.115 & 0.64 & 0.493 & 160 \\
& $\mathrm{TP}$ & -17.557 & 1.344 & 0.81 & 0.385 & 150 \\
\hline & $\mathrm{TOC}$ & -9.709 & 1.166 & 0.75 & 0.346 & 251 \\
& $\mathrm{TKN}$ & -16.039 & 1.325 & 0.78 & 0.357 & 254 \\
& $\mathrm{NO}_{3}+\mathrm{NO}_{2}$ & -10.616 & 1.132 & 0.63 & 0.446 & 267 \\
& $\mathrm{TP}$ & -21.891 & 1.492 & 0.82 & 0.358 & 259 \\
\hline
\end{tabular}

The mass inputs and outputs estimated from the model were summed over time to provide monthly and annual total mass loads for the period from 1978-2004. Annual retention rates $\left(R_{i}\right)$ of TOC, TKN, $\mathrm{NO}_{3}+\mathrm{NO}_{2}$ and TP were calculated by: 


$$
R_{i}=\frac{S_{\text {in }}-S_{\text {out }}}{S_{\text {in }}} \times 100
$$

where $S_{\text {in }}$ is total mass inflow of an element at Simmesport, and $S_{\text {out }}$ is total mass outflow of an element at Morgan City and Wax Lake Outlet.

A paired $t$ test was used to evaluate the significance of differences in TOC, TKN, $\mathrm{NO}_{3}+\mathrm{NO}_{2}$ and TP concentrations between the inflowing water at Simmesport and outflowing water at Morgan City and Wax Lake Outlet. Regression analysis was used to determine relationships between nitrogen removal and the basin hydrology. All statistical analyses were performed with the SAS Statistical Software package [13].

\section{Results}

\subsection{Hydrologic Characteristics of the Atchafalaya}

During the 27 years from 1978 and 2004, river discharge at Simmesport (inflow) averaged $6547 \mathrm{~m}^{3} \mathrm{~s}^{-1}$, varying from 1246 in to $19,255 \mathrm{~m}^{3} \mathrm{~s}^{-1}$. During the same period, daily average discharge at Morgan City and Wax Lake Outlet (outflow) was $6436 \mathrm{~m}^{3} \mathrm{~s}^{-1}$, varying from 1028 to $17,878 \mathrm{~m}^{3} \mathrm{~s}^{-1}$. On an annual average, a total volume of $2.07 \times 10^{11} \mathrm{~m}^{3}$ water flowed into the Atchafalaya at Simmesport and a total volume of $2.03 \times 10^{11} \mathrm{~m}^{3}$ water left the basin at Wax Lake Outlet and Morgan City.

Seasonally, both discharge and its interannual variability were high from March to June and low from August to November (Figure 2). During the high flow period (December-June) the inflow was significantly higher than the outflow (Figure 3), suggesting that the basin served as a recharge zone from winter to late spring. During the low flow period from August to November, however, the outflow often exceeded the inflow, indicating that the basin served as a discharge zone.

Figure 2. Seasonal trend of discharge into the Atchafalaya. The solid area represents discharge within 25 th-75th percentiles, and the vertical lines represent maximum and minimum daily discharge.

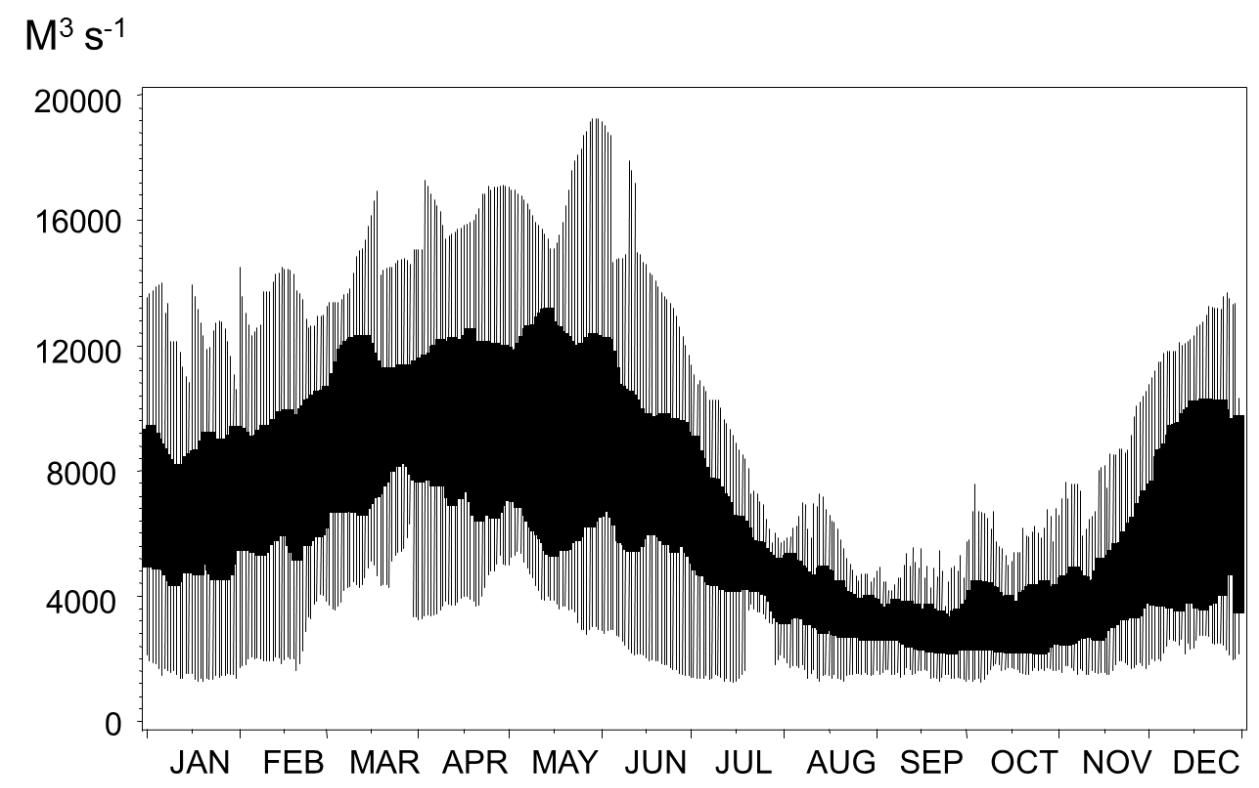


Figure 3. Monthly river inflow_outflow balance with an error confidence limit, $p=0.95$.

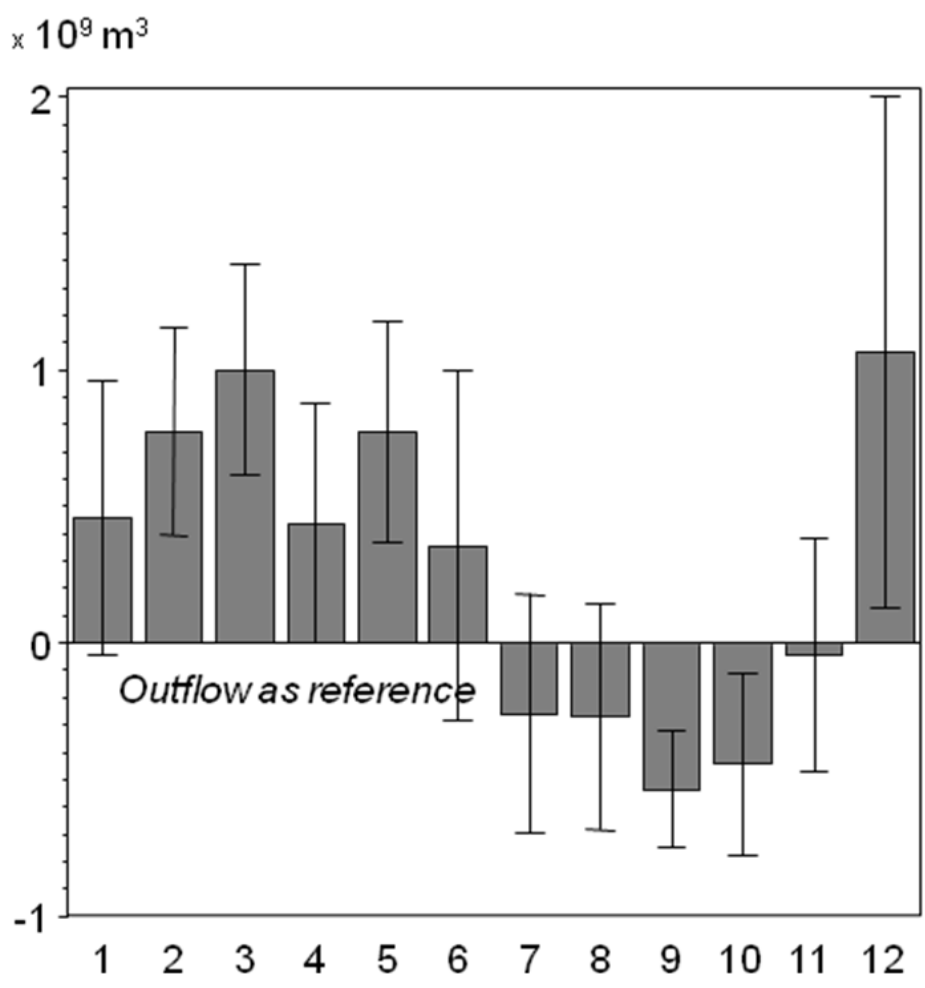

\subsection{Riverine Carbon, Nitrogen, and Phosphorus Concentrations}

Over the past 27 years, the Atchafalaya showed consistently higher concentrations of total organic carbon (with few exceptions), total Kjeldahl nitrogen, and total phosphorus in the inflow waters at Simmesport than those in the outflow waters at Morgan City (Figure 4). TOC concentrations varied from 1.50 to $18.00 \mathrm{mg} \mathrm{L}^{-1}$ in the inflow, with an average concentration of $6.29 \mathrm{mg} \mathrm{L}^{-1}$, and from 1.50 to $19.00 \mathrm{mg} \mathrm{L}^{-1}$ in the outflow, with an average concentration of $5.71 \mathrm{mg} \mathrm{L}^{-1}$. The difference in TOC concentration between in and outflow was statistically significant (Table 2). Seasonally, both inflow and outflow showed higher TOC concentrations during the late winter and spring months and low TOC concentrations in August and September.

TKN and TP concentrations in the Atchafalaya River displayed a similar trend to that of TOC (Figure 4). The inflow waters at Simmesport showed an average TKN concentration of $0.97 \mathrm{mg} \mathrm{L}^{-1}$, varying from 0.31 to $2.80 \mathrm{mg} \mathrm{L}^{-1}$, and an average TP concentration of $0.28 \mathrm{mg} \mathrm{L}^{-1}$, varying from 0.09 to $0.89 \mathrm{mg} \mathrm{L}^{-1}$. Both TKN and TP concentrations in the inflow waters were significantly higher than those in the outflow waters at Morgan City (Table 2)-TKN: $0.73 \mathrm{mg} \mathrm{L}^{-1}$ ranging from 0.16 to $1.86 \mathrm{mg} \mathrm{L}^{-1}$; TP: $0.19 \mathrm{mg} \mathrm{L}^{-1}$ ranging from 0.02 to $0.64 \mathrm{mg} \mathrm{L}^{-1}$. 
Figure 4. Long-term (1978-2004) average monthly concentrations of total organic carbon (TOC), total Kjeldahl nitrogen (TKN), nitrate/nitrite nitrogen $\left(\mathrm{NO}_{3}+\mathrm{NO}_{2}\right)$, and total phosphorus (TP) in the inflow waters at Simmesport (solid lines) and outflow waters at Morgan City (dashed lines) in the Atchafalaya River.

Concentration $\left(\mathrm{mg} \mathrm{L}^{-1}\right)$
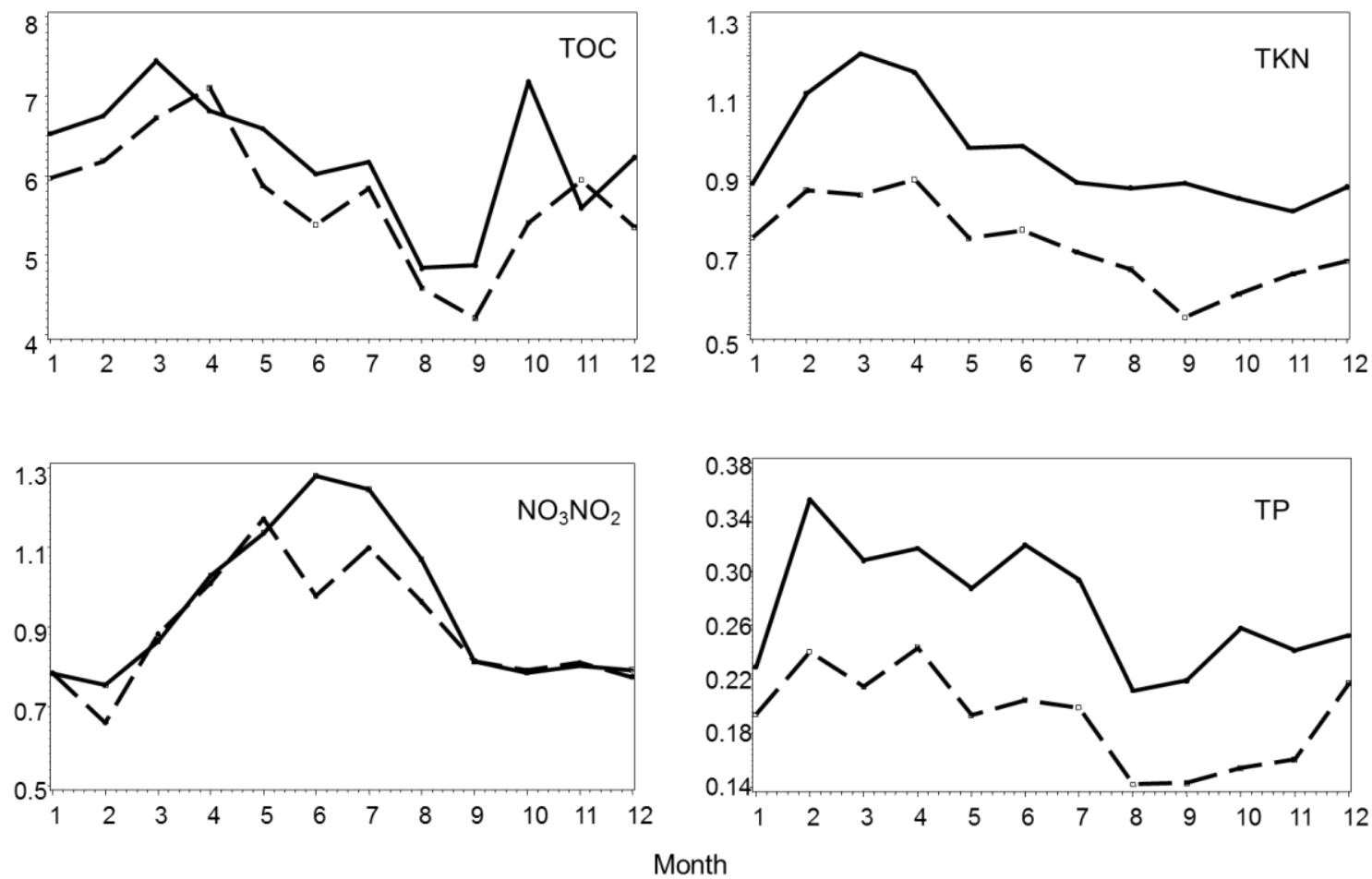

Table 2. Average concentrations of total organic carbon (TOC), total Kjeldahl nitrogen (TKN), nitrate and nitrite nitrogen $\left(\mathrm{NO}_{3}+\mathrm{NO}_{2}\right)$, and total phosphorus (TP) observed at the upstream (Simmesport) and downstream (Morgan City) locations.

\begin{tabular}{ccccc}
\hline & \multicolumn{1}{c}{ Simmesport } & $\begin{array}{c}\text { Morgan City } \\
\text { Mean } \pm \text { SE }\left(\mathbf{m g ~ L}^{-\mathbf{1}}\right)\end{array}$ & diff & \\
& \multicolumn{2}{c}{$\boldsymbol{p}>|\boldsymbol{t}|$} \\
$\mathrm{TOC}$ & $6.32 \pm 0.19$ & $5.71 \pm 0.14$ & 0.61 & $<0.0001$ \\
$\mathrm{TKN}$ & $0.97 \pm 0.03$ & $0.73 \pm 0.02$ & 0.24 & $<0.0001$ \\
$\mathrm{NO}_{3}+\mathrm{NO}_{2}$ & $0.89 \pm 0.03$ & $0.94 \pm 0.03$ & -0.05 & $=0.9498$ \\
$\mathrm{TP}$ & $0.28 \pm 0.01$ & $0.19 \pm 0.01$ & 0.09 & $<0.0001$ \\
\hline
\end{tabular}

Nitrate/nitrite concentrations in the Atchafalaya River, however, showed a reversed trend in terms of both seasonality and the upstream-downstream relation (Figure 4). The average $\mathrm{NO}_{3}+\mathrm{NO}_{2}$ concentration in the inflow waters $\left(0.90 \mathrm{mg} \mathrm{L}^{-1}\right.$, ranging from 0.15 to $\left.2.56 \mathrm{mg} \mathrm{L}^{-1}\right)$ was lower than that in the outflow waters $\left(0.95 \mathrm{mg} \mathrm{L}^{-1}\right.$, ranging from 0.17 to $\left.2.38 \mathrm{mg} \mathrm{L}^{-1}\right)$, although the difference was not statistically significant. There was a clear seasonal trend with the highest $\mathrm{NO}_{3}+\mathrm{NO}_{2}$ concentrations in the summer months and the lowest in the winter and late fall. 


\subsection{Mass Inflow, Outflow and Retention of Carbon, Nitrogen and Phosphorus}

Mass transport of nutrients and organic carbon in the Atchafalaya River showed a similar seasonal trend to that of the river flow (Figure 5). From 1978 to 2004, on an annual average, a total of $1306.2 \times 10^{3} \mathrm{t}$ TOC, $199.6 \times 10^{3} \mathrm{t} \mathrm{TKN}, 169.1 \times 10^{3} \mathrm{t} \mathrm{NO}_{3}+\mathrm{NO}_{2}$, and $58.2 \times 10^{3} \mathrm{t}$ TP entered into the Atchafalaya River at Simmesport (Table 3). For the same period of time, the river discharged annually a total of $1139.1 \times 10^{3} \mathrm{t} \mathrm{TOC,} 151.1 \times 10^{3} \mathrm{t} \mathrm{TKN}, 179.3 \times 10^{3} \mathrm{t} \mathrm{NO}_{3}+\mathrm{NO}_{2}$, and $41.3 \times 10^{3} \mathrm{t} \mathrm{TP}$ at Wax Lake Outlet and Morgan City into the Gulf of Mexico. Fluctuation in the mass transport of the elements was great from low to high, a difference in magnitude of 2.5-3 fold, corresponding to the fluctuation in river discharge from the drier year of 2000 to the wetter year of 1993 (Table 3).

Figure 5. Long-term average monthly loads of total organic carbon (TOC), total Kjeldahl nitrogen $(\mathrm{TKN})$, nitrate/nitrite nitrogen $\left(\mathrm{NO}_{3}+\mathrm{NO}_{2}\right)$, and total phosphorus (TP) in the inflow waters at Simmesport (solid lines) and outflow waters at Morgan City (dashed lines) in the Atchafalaya River.
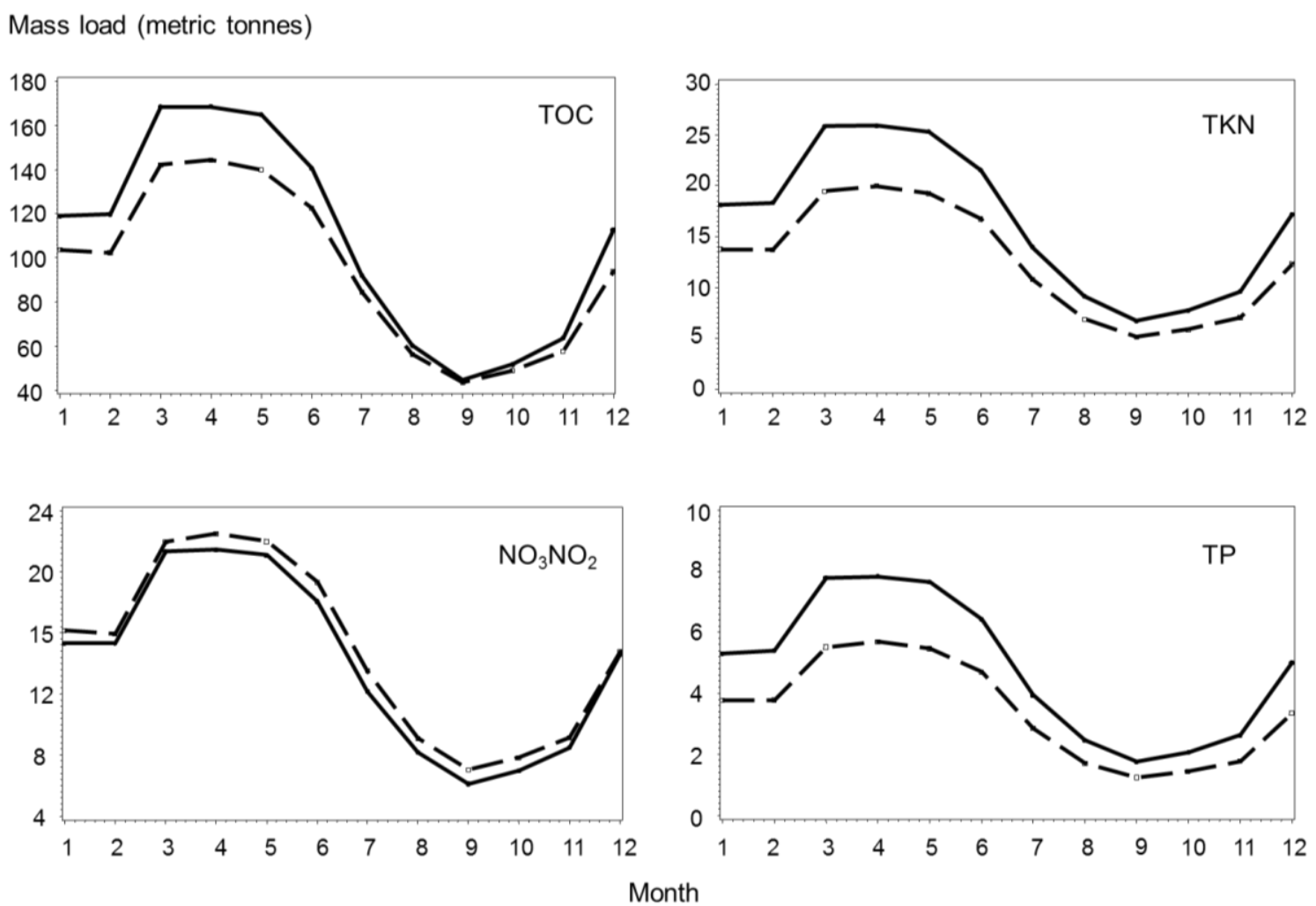

The inflow-outflow budget calculation showed a $13 \%$ reduction of TOC, a $24 \%$ reduction of TKN, a 29 reduction of TP, but a $6 \%$ increase of $\mathrm{NO}_{3}+\mathrm{NO}_{2}$. Annual total nitrogen inflow (sum of TKN and $\mathrm{NO}_{3}+\mathrm{NO}_{2}$ ) was $368.7 \times 10^{3}$ t, of which $\mathrm{TKN}$ accounted for $54 \%$. In the annual total nitrogen outflow, $330.4 \times 10^{3} \mathrm{t}$, the proportion of TKN reduced to $46 \%$. 
Table 3. Annual inflow-outflow budgets of total organic carbon (TOC), total Kjeldahl nitrogen (TKN), nitrate and nitrite nitrogen $\left(\mathrm{NO}_{3}+\mathrm{NO}_{2}\right)$, and total phosphorus (TP) for the Atchafalaya River Basin.

\begin{tabular}{|c|c|c|c|c|c|c|c|c|c|c|c|c|}
\hline \multirow{2}{*}{ Year } & \multicolumn{3}{|c|}{ TOC * $\left(\times 10^{3} t\right)$} & \multicolumn{3}{|c|}{ TKN ** $\left(\times 10^{3} t\right)$} & \multicolumn{3}{|c|}{$\mathrm{NO}_{3}+\mathrm{NO}_{2}\left(\times 10^{3} \mathrm{t}\right)$} & \multicolumn{3}{|c|}{$\mathrm{TP}\left(\times 10^{3} t\right)$} \\
\hline & In & Out & $\pm \Delta \%$ & In & Out & $\pm \Delta \%$ & In & Out & $\pm \Delta \%$ & In & Out & $\pm \Delta \%$ \\
\hline 1978 & 1114.5 & 984.6 & 11.7 & 170.6 & 128.6 & 24.6 & 147.9 & 156.2 & -5.6 & 48.8 & 34.4 & 29.6 \\
\hline 1979 & 1806.6 & 1528.0 & 15.4 & 274.9 & 208.9 & 24.0 & 227.8 & 236.6 & -3.9 & 82.3 & 59.2 & 28.1 \\
\hline 1980 & 1001.4 & 900.8 & 10.0 & 153.6 & 117.2 & 23.7 & 132.2 & 143.1 & -8.3 & 43.4 & 30.8 & 29.0 \\
\hline 1981 & 811.6 & 746.0 & 8.1 & 123.5 & 94.4 & 23.5 & 110.1 & 120.8 & -9.7 & 34.1 & 24.1 & 29.4 \\
\hline 1982 & 1310.3 & 1131.1 & 13.7 & 201.6 & 150.4 & 25.4 & 173.5 & 181.1 & -4.4 & 58.6 & 40.9 & 30.2 \\
\hline 1983 & 1738.2 & 1474.4 & 15.2 & 267.1 & 205.5 & 23.1 & 222.2 & 231.5 & -4.2 & 81.1 & 58.7 & 27.6 \\
\hline 1984 & 1522.9 & 1308.4 & 14.1 & 232.3 & 175.4 & 24.5 & 197.9 & 207.1 & -4.7 & 68.6 & 48.7 & 29.1 \\
\hline 1985 & 1452.6 & 1254.3 & 13.7 & 221.4 & 166.9 & 24.6 & 187.0 & 196.5 & -5.1 & 65.4 & 46.3 & 29.1 \\
\hline 1986 & 1231.2 & 1084.3 & 11.9 & 187.5 & 141.2 & 24.7 & 161.6 & 172.1 & -6.5 & 54.0 & 38.2 & 29.3 \\
\hline 1987 & 934.9 & 844.5 & 9.7 & 142.6 & 107.2 & 24.8 & 122.8 & 132.8 & -8.1 & 40.0 & 28.0 & 29.8 \\
\hline 1988 & 871.6 & 798.2 & 8.4 & 132.2 & 102.5 & 22.4 & 113.0 & 124.7 & -10.3 & 37.6 & 27.2 & 27.7 \\
\hline 1989 & 1399.0 & 1213.8 & 13.2 & 213.0 & 161.5 & 24.2 & 177.6 & 188.4 & -6.0 & 62.2 & 44.2 & 29.0 \\
\hline 1990 & 1524.4 & 1297.1 & 14.9 & 235.5 & 175.3 & 25.6 & 194.7 & 203.3 & -4.4 & 70.1 & 49.2 & 29.7 \\
\hline 1991 & 1624.9 & 1387.4 & 14.6 & 249.2 & 189.2 & 24.1 & 207.2 & 216.0 & -4.3 & 74.9 & 53.6 & 28.4 \\
\hline 1992 & 1091.8 & 974.2 & 10.8 & 166.1 & 124.0 & 25.3 & 143.5 & 154.3 & -7.5 & 46.7 & 32.6 & 30.2 \\
\hline 1993 & 1954.1 & 1539.7 & 21.2 & 299.8 & 209.2 & 30.2 & 248.7 & 241.0 & 3.1 & 90.2 & 58.6 & 35.1 \\
\hline 1994 & 1353.5 & 1160.0 & 14.3 & 207.0 & 154.5 & 25.3 & 174.6 & 183.3 & -5.0 & 60.7 & 42.5 & 30.1 \\
\hline 1995 & 1223.4 & 1138.7 & 6.9 & 186.7 & 149.5 & 19.9 & 158.9 & 178.4 & -12.3 & 53.9 & 40.4 & 25.0 \\
\hline 1996 & 1356.3 & 1137.0 & 16.2 & 207.1 & 147.6 & 28.8 & 175.7 & 178.6 & -1.6 & 60.1 & 39.8 & 33.7 \\
\hline 1997 & 1489.5 & 1278.1 & 14.2 & 228.2 & 173.4 & 24.0 & 190.6 & 198.9 & -4.3 & 68.1 & 48.6 & 28.6 \\
\hline 1998 & 1477.6 & 1311.2 & 11.3 & 226.0 & 177.8 & 21.3 & 190.2 & 208.0 & -9.4 & 66.5 & 49.0 & 26.4 \\
\hline 1999 & 1189.1 & 1058.4 & 11.0 & 181.6 & 139.1 & 23.4 & 154.2 & 168.4 & -9.3 & 52.7 & 38.2 & 27.6 \\
\hline 2000 & 743.3 & 650.8 & 12.5 & 112.5 & 78.8 & 29.9 & 99.6 & 103.6 & -4.1 & 30.5 & 19.6 & 35.5 \\
\hline 2001 & 1181.5 & 1064.2 & 9.9 & 180.2 & 139.3 & 22.7 & 153.9 & 168.2 & -9.3 & 51.7 & 37.4 & 27.8 \\
\hline 2002 & 1298.7 & 1190.6 & 8.3 & 197.4 & 159.0 & 19.5 & 166.2 & 187.0 & -12.5 & 57.1 & 43.9 & 23.1 \\
\hline 2003 & 1160.5 & 1065.5 & 8.2 & 176.9 & 139.5 & 21.1 & 151.5 & 168.5 & -11.3 & 50.5 & 37.6 & 25.7 \\
\hline 2004 & 1405.1 & 1235.8 & 12.1 & 214.6 & 162.4 & 24.3 & 182.0 & 192.7 & -5.9 & 62.3 & 43.7 & 29.7 \\
\hline mean & 1306.2 & 1139.1 & 12.3 & 199.6 & 151.1 & 24.3 & 169.1 & 179.3 & -6.5 & 58.2 & 41.3 & 29.1 \\
\hline
\end{tabular}




\section{Discussion}

Based on their organic carbon concentration data from river water samples collected between July 1976 and June 1977, Lambou and Hern [14] estimated an annual inflow of $1120 \times 10^{3}$ t TOC into the Atchafalaya River, The estimate is lower than both the long-term average inflow $\left(1306.2 \times 10^{3} \mathrm{t}\right)$ and outflow of TOC $\left(1139.1 \times 10^{3}\right)$ found in this study. Malcolm and Durum [15] reported a $2000 \times 10^{3} \mathrm{t}$ of dissolved organic carbon (DOC) output from the Mississippi-Atchafalaya River system, which may be too low, considering the fact that the Atchafalaya River carries approximately $30 \%$ of the Mississippi's flow.

The riverine organic matter was observed to be soil-derived and refractory [16]. It is suspected that terrestrial organic carbon must undergo an estuarine mixing process [17]. Many studies have demonstrated that microbial degradation and photochemical oxidation have played an important role in the removal of terrestrial DOC in coastal waters [18-22]. The sedimentation and chemical absorption mechanism may also remove nutrients in the river and wetland systems [23]. Using terrestrially derived lignin phenols as bio-markers, Benner and Opsahl [24] found that photo-oxidation was the major removal process of the terrestrial DOC, and that the photochemical reactions mainly occurred in higher salinity waters, while flocculation and microbial degradation were more dominant in terrestrial DOC removal from low salinity waters in the Mississippi River estuary. The organic carbon retention found in this study may have also been influenced by these factors.

Nutrients can enter streams and rivers through direct surface runoff, subsurface leaching and agricultural drains. More than $20 \times 10^{6}$ hectares of land have been drained through use of subsurface tile drainage, ditches and streams in many states of the Upper Mississippi River Basin [25]. This drainage practice can result in the leaching of large amounts of dissolved organic carbon and nutrients stored in soils [3,26]. Soil tillage and fertilization can cause elevated concentrations of nutrients in the streams. These agricultural practices are common in the upper Mississippi River Basin, which may have been another reason for the higher TKN and phosphorus concentrations in the late winter and spring. In a simulation study on the impact of agricultural practices on the doubled nitrogen export from the Upper Mississippi River Basin since the 1960s, Donner and others [27] found the three critical factors were: (a) an increase in fertilizer application; (b) an increase in runoff across the basin; and (c) the expansion of soybean cultivation. In this study, the decrease of TKN and phosphorus concentrations from the spring towards the summer and fall may have exposed the direct influence of the runoff from the Upper Mississippi River Basin. On the other hand, the concentrations of $\mathrm{NO}_{3}+\mathrm{NO}_{2}$ in the Atchafalaya River were synchronized with the seasonal trend of temperature (Figure 4), suggesting a strong biological influence on riverine nitrogen transformation in the Atchafalaya.

Based on their data synthesis study, Kadlec and Knight [28] reported that on average, one hectare of natural wetland was able to remove $1.89 \mathrm{~kg}$ nitrogen per day. The Atchafalaya River has a wide floodplain with many braided channels, sloughs, and meanders. As the volume of water flowing through the basin increases, the proportion of the floodplain covered with water increases. Riverine nitrogen can undergo a series of transformations during flooding. It can be retained by river and wetland systems through filtration, sedimentation, chemical absorption, microbial interactions and uptake by vegetation [23]. In the Atchafalaya, all of these processes may have occurred simultaneously in the past, because it is a large river system with many braided channels, floodplains, backwater 
swamps and bottomland hardwood ecosystems. A study by Donner and others [29] showed that benthic denitrification may play a significant role in nitrogen removal in the Mississippi River. From another recent study on sediment inflow and outflow (1978-2004) in the Atchafalaya, Xu [30] found an average retention of 6 million tonnes suspended sediment (or 9\%) occurred each year in the basin. The high retention rates of organic nitrogen and total phosphorus found in this study may have also been partially associated with the sedimentation process in this large river swamp basin.

This study shows that retention rates of TOC, TKN, and TP in the Atchafalaya River Swamp basin are closely correlated with the river inflow at Simmesport (Figure 6). About $83 \%$ of the variation in average monthly TOC retention, $85 \%$ of the variation in average monthly TKN retention, and $89 \%$ of the variation in average monthly TP retention can be explained by the amount of average monthly inflow in a linear regression function. Many wetlands along the Atchafalaya are backwater cypress-tupelo swamps. Hydrologically, these swamp systems serve as retention basins when the water level in the channels rises. When the water level falls, they become discharge areas and are then disconnected with the channels. Biogeo chemically, the swamps are active ecosystems in nutrient cycling and exchange with the riverine water.

Figure 6. Influence of the river inflow $\left(Q_{i n}\right)$ on retention rates of total organic carbon (TOC), total Kjeldahl nitrogen (TKN), nitrate/nitrite nitrogen $\left(\mathrm{NO}_{3}+\mathrm{NO}_{2}\right)$, and total phosphorus (TP) in the Atchafalaya River.
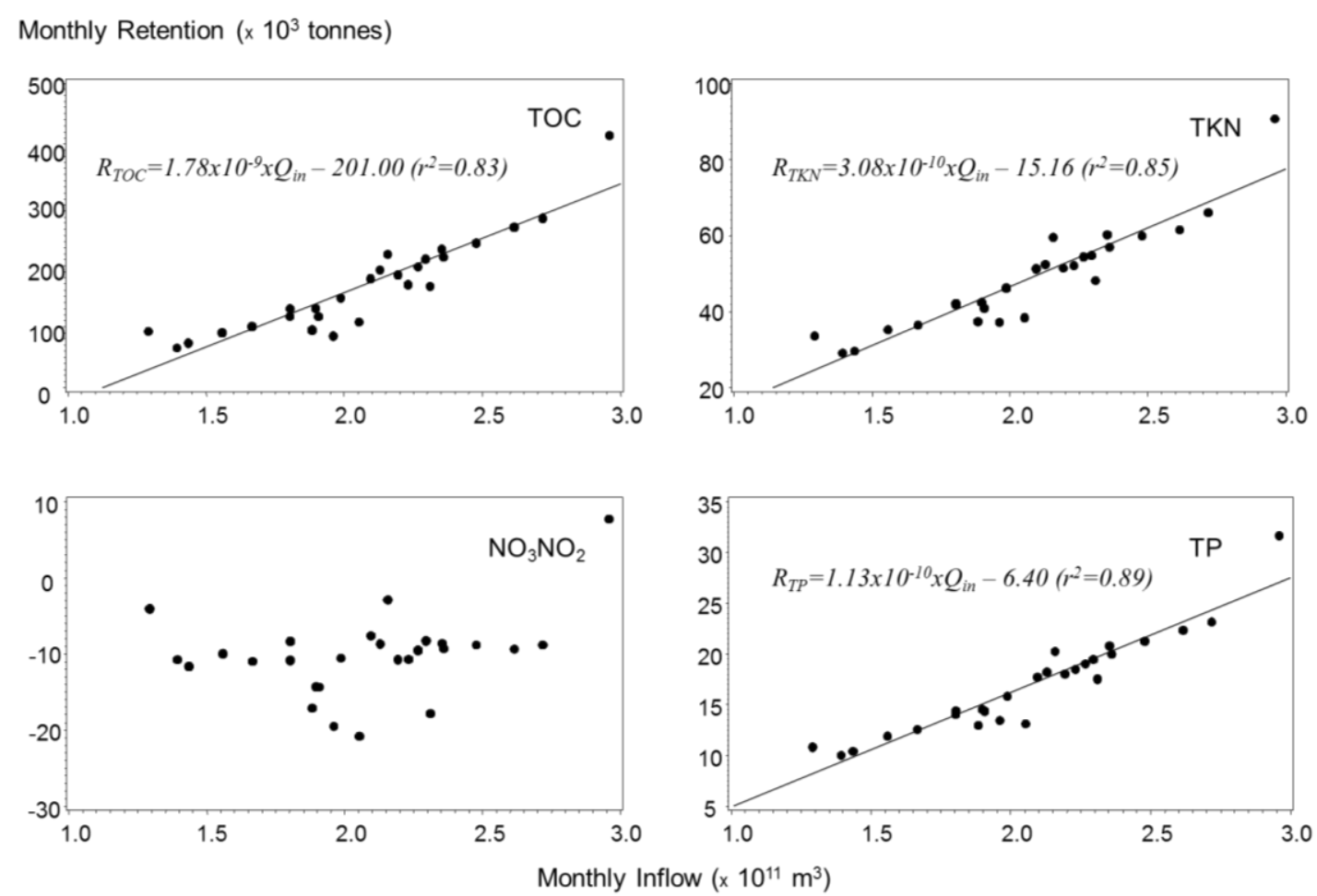

In contrast to organic carbon, organic nitrogen and total phosphorus, changes in annual mass input-output balance of nitrate and nitrite nitrogen were not related to the basin discharge (Figure 6). In fact, this study showed a negative inflow-outflow budget of nitrate and nitrite nitrogen for 26 out of 27 years (Table 3). The result contradicts findings from other studies that reported various nitrate reduction rates in freshwater wetlands [31], river and stream sediments [32], and constructed wetlands [33], ranging widely from a few milligrams to several thousand milligrams per square meter 
per day. However, the negative budget does not necessarily mean that denitrification is not occurring in the Atchafalaya, but rather that nitrate + nitrite becomes the principle nitrogen cycling product either from transformation leading to significant reduction of TKN, or from the large biomass storage within the river corridor and floodplain wetlands, or from both.

To test the hypothesis that river corridor wetlands and floodplains function as an effective sink for riverine nitrate during an extreme flood event, BryantMason et al. [34] analyzed changes in isotope $\delta^{15} \mathrm{~N}_{\mathrm{NO} 3}$ and $\delta^{18} \mathrm{O}_{\mathrm{NO} 3}$ values of flood waters collected at Simmersport and Morgan City during the 2011 Mississippi River spring flood. They found that despite the widespread high floods of the Atchafalaya River Basin, the total nitrate + nitrite mass inflow $(89,600 \mathrm{t})$ was reduced by only about $7 \%$ at the basin's two outlets. The result strongly suggests that flow-through systems such as river corridor wetlands and floodplains may be ineffective in reducing riverine nitrate during a flood event because of limited residence time. Another study on the long-term (1980-2008) nitrate delivery of the Mississippi River [35] reported that nitrate concentrations at eight major monitoring sites either changed very little ( 3 sites) or increased by 9\%-67\% (5 sites). Using a mass balance approach, Alexander et al. [36] analyzed the in-stream loss of nitrate at 374 monitoring stations spread out from the headwaters to the high order streams in the lower Mississippi River basin. They found that nitrate loss in these riverine systems decreased with increasing channel size. In the Atchafalaya, there are many braided channels and their sizes change widely depending on the river flood stage. The finding that the mass output of nitrate + nitrite nitrogen was higher than their mass input, especially during the spring and summer, indicates the complexity of biological and hydrometeorological impacts on nitrogen transformation and transport from this swamp basin. Furthermore, the lack of a relationship between river discharge and nitrate + nitrite budget suggest that riverine nitrogen within the Atchafalaya swamp basin may undergo a considerable variability in residence time.

\section{Conclusions}

This assessment of long-term data on nutrients and carbon in the Atchafalaya River shows that river corridor wetlands and floodplains can remove considerable amounts of total Kjeldahl nitrogen, total phosphorus, and total organic carbon. On the contrary, however, more nitrate and nitrite leave the river basin than enter it, suggesting that the Atchafalaya River Basin functions as a source of the nitrogen species. The removal rates of Kjeldahl nitrogen, total phosphorus, and total organic carbon are closely and positively related to the river discharge, indicating that settling of particles that carry the elements over the flooded areas may be the main cause for the removal.

\section{Acknowledgements}

The author thanks the New Orleans District Office of the U.S. Army Corps of Engineers and the Louisiana District of the U.S. Geological Survey for providing the long-term river discharge records. Thanks also go to the Louisiana Department of Environmental Quality for making the long-term water quality data available for this study. The author is grateful for two anonymous reviewers for their helpful comments on the manuscript. 


\section{References}

1. Xu, Y.J.; BryantMason, A. Determining the Nitrate Contribution of the Red River to the Atchafalaya River in the Northern Gulf of Mexico under Changing Climate. In Water Quality: Current Trends and Expected Climate Change Impacts; Peters, J., Ed.; IAHS Publication 348; IAHS Press: Wallingford, UK, 2011; pp. 95-100.

2. Turner, R.E.; Rabalais, N.N. Coastal eutrophication near the Mississippi River Delta. Nature 1994, 368, 619-621.

3. Goolsby, D.A.; Battaglin, W.A.; Aulenbach, B.T.; Hooper, R.P. Nitrogen input to the Gulf of Mexico. J. Environ. Quality 2001, 30, 329-336.

4. Rabalais, N.N.; Diaz, R.J.; Levin, L.A.; Turner, R.E.; Gilbert, D.; Zhang, J. Dynamics and distribution of natural and human-caused coastal hypoxia. Biogeosciences 2010, 7, 585-619.

5. Turner, R.E.; Rabalais, N.N. Changes in Mississippi River water quality this century. Bioscience 1991, 41, 140-147.

6. Rabalais, N.N.; Turner, R.E.; Justic, D.; Dortch, Q.; Wiseman, W.J., Jr.; Sen Gupta, B.K. Nutrient changes in the Mississippi River, and system responses on the adjacent continental shelf. Estuaries 1996, 19, 386-407.

7. Rabalais, N.N.; Turner, R.E.; Wiseman, W.J., Jr.; Dortch, Q. Consequences of the 1993 Mississippi River flood in the gulf of Mexico. Regul. Rivers Res. Manag. 1998, 14, 161-177.

8. Rabalais, N.N.; Turner, R.E.; Scavia, D. Beyond science into policy: Gulf of Mexico hypoxia and the Mississippi river. BioScience 2002, 52, 129-142.

9. Mississippi River/Gulf of Mexico Watershed Nutrient Task Force, 2008. Gulf of Mexico Action Plan 2008. Available online: http://water.epa.gov/type/watersheds/named/msbasin/actionplan.cfm (accessed on 27 March 2013).

10. $\mathrm{Xu}, \mathrm{Y} . J$. Total nitrogen inflow and outflow from a large river swamp basin to the Gulf of Mexico. Hydrol. Sci. J. 2006, 51, 531-542.

11. Xu, Y.J.; Patil, A. Organic carbon fluxes from the Atchafalaya River into the Gulf of Mexico. In Coastal Environment and Water Quality; Xu, Y.J., Singh, V.P., Eds.; Water Resources Publications: Highlands Ranch, CO, USA, 2006; pp. 217-226.

12. Murphy, K.E.; Touchet, B.A.; White, A.G.; Daigle, J.J.; Clark, H.L. Soil survey of St Martin Parish, Louisiana, U.S.; Department of Agriculture Soil Conservation Service: Washington, DC, USA, 1977.

13. SAS/STAT User's Guide, Version 6.12, 4th ed.; SAS Institute Inc.: Cary, NC, USA, 1996.

14. Lambou, V.W.; Hern, S.C. Transport of organic-carbon in the Atchafalaya Basin, Louisiana. Hydrobiologia 1983, 98, 25-34.

15. Malcolm, R.L.; Durum, W.H. Organic Carbon and Nitrogen Concentration and Annual Carbon Load of Six Selected Rivers in United States; USGS Water Supply paper 1817F; U.S. Government Printing Office: Washington, DC, USA, 1976.

16. Dittmar, T.; Kattner, G. Recalcitrant dissolved organic matter in the ocean: Major contribution of small amphiphilics. Mar. Chem. 2003, 82, 115-123. 
17. Hedges, J.I.; Keil, R.G.; Benner, R. What happens to terrestrial organic matter in the ocean? Org. Geochem. 1997, 27, 195-212.

18. Benner, R.; Opsahl, S.; ChinLeo, G.; Richey, J.E.; Forsberg, B.R. Bacterial carbon metabolism in the Amazon River system. Limnol. Oceanogr. 1995, 40, 1262-1270.

19. Miller, W.L.; Moran, M.A. Interaction of photochemical and microbial processes in the degradation of refractory dissolved organic matter from a coastal marine environment. Limnol. Oceanogr. 1997, 42, 1317-1324.

20. Opsahl, S.; Benner, R. Distribution and cycling of terrigenous dissolved organic matter in the ocean. Nature 1997, 386, 480-482.

21. Coffin, R.B.; Cifuentes, L.A. Stable isotope analysis of carbon cycling in the Perdido Estuary, Florida. Estuaries 1999, 22, 917-926.

22. Raymond, P.A.; Bauer, J.E. DOC cycling in a temperate estuary: A mass balance approach using natural ${ }^{14} \mathrm{C}$ and ${ }^{13} \mathrm{C}$ isotopes. Limnol. Oceanogr. 2001, 46, 655-667.

23. Watson, J.T.; Reed, S.C.; Kadlec, R.H.; Knight, R.L.; Whitehouse, A.E. Performance Expectations and Loading Rates for Constructed Wetlands. In Constructed Wetlands for Wastewater Treatment; Hammer, D.A., Ed.; Lewis Publishers: Chelsea, MI, USA, 1989; pp. 319-351.

24. Benner, R.; Opsahl, S. Molecular indicators of the sources and transformations of dissolved organic matter in the Mississippi river plume. Org. Geochem. 2001, 32, 597-611.

25. U.S. Department of Agriculture. Farm Drainage in the United States: History, Status, and Prospects; Economic Research Service, Miscellaneous Publ. No. 1455; U.S. Department of Agriculture: Washington, DC, USA; 1987.

26. Goolsby, D.A.; Battaglin, W.A.; Lawrence, G.B.; Artz, R.S.; Aulenbach, B.T.; Hooper, R.P. Flux and Sources of Nutrients in the Mississippi-Atchafalaya Basin; Topic 3 Report for the Integrated Assessment on Hypoxia in the Gulf of Mexico. Silver Spring (MD); NOAA Coastal Ocean Office: Silver Spring, MD, USA, 1999; Decision Analysis Series No. 17.

27. Donner, S.D.; Kucharik, C.J.; Foley, J.A. Impact of changing land use practices on nitrate export by the Mississippi River. Glob. Biogeochem. Cycles 2004, 18, Article No. GB1028.

28. Kadlec, R.H.; Knight, R.L. Treatment Wetlands; Lewis Publishers: New York, NY, USA, 1996.

29. Donner, S.D.; Kucharik, C.J.; Oppenheimer, M. The influence of climate on in-stream removal of nitrogen. Geophys. Res. Lett. 2004, 31, Article No. L20509.

30. Xu, Y.J. Long-Term Sediment Transport and Delivery of the Largest Distributary of the Mississippi River, the Atchafalaya, USA. In Sediment Dynamics for a Changing Future; Banasik, K., Horowitz, A., Owens, P.N., Stone, M., Walling, D.E., Eds.; IAHS Publication 337, Wallingford, UK, 2010; pp. 282-290.

31. Buresh, R.J.; Reddy, K.R.; van Kessel, C. Nitrogen Transformations in Submerged Soils. In Nitrogen in Agricultural Systems. Agronomy Monograph 49; Schepers, J.S., Raun, W.R., Eds.; American Society of Agronomy, Crop Science Society of America, Soil Science Society of America: Madison, WI, USA, 2008; pp. 401-436.

32. Seitzinger, S.P. Denitrification in fresh-water and coastal marine ecosystems-Ecological and geochemical significance. Limnol. Oceanogr. 1988, 33, 702-724. 
33. Knight, R.L.; Kadlec, R.H.; Ohlendorf, H.M. The use of treatment wetlands for petroleum industry effluents. Environ. Sci. Technol. 1999, 33, 973-980.

34. BryantMason, A.; Xu, Y.J.; Altabet, M.A. Limited capacity of river corridor wetlands to remove nitrate: A case study on the Atchafalaya River Basin during the 2011 Mississippi River Flooding. Water Resour. Res. 2013, 49, 283-290.

35. Sprague, L.A.; Hirsch, R.M.; Aulenbach, B.T. Nitrate in the Mississippi River and its tributaries, 1980 to 2008: Are we making progress? Environ. Sci. Technol. 2011, 45, 7209-7216.

36. Alexander, R.B.; Smith, R.A.; Schwarz, G.E. Effect of stream channel size on the delivery of nitrogen to the Gulf of Mexico. Nature 2000, 403, 758-761.

(C) 2013 by the authors; licensee MDPI, Basel, Switzerland. This article is an open access article distributed under the terms and conditions of the Creative Commons Attribution license (http://creativecommons.org/licenses/by/3.0/). 